\title{
NARRATIVE SCHOLAR AND NARRATED LIVES: LIFE WRITING AND (SELF-)REPRESENTATION
}

\author{
Kristin Kuutma
}

\begin{abstract}
This presentation discusses some aspects of narrative, or narrated, representation by combining life narrative, life-writing and reflexive investigation into disciplinary history, i.e. the progress of academic folkloristics in the early 20th century. The broader theoretical and methodological questions dovetail with the philosophical concerns of history writing, but also with the generic strategies and narrative modes emergent in biographical writing.

The historical perspective focuses on a key figure in Estonian folkloristics and folk narrative research, Matthias Johann Eisen (1857-1934). He was a highly productive collector of expressive culture in narrative form, but also a prolific author and editor of numerous volumes. The current study will focus on narratives which represent this seminal cultural figure for posterity in biographical or autobiographical essays and memoirs, while aiming to analyse Eisen's public and self-referential representation, based on publications and manuscripts engaged in constructing his life narrative. This perspective on narrative discourse combines a critical examination of historical representation with a reflexive analysis of individual portrayals created by selves and others in the process, guided by the perception of constructedness and representational contingencies of the writing of life history. Such analysis of life writing includes an insight into the politics of remembering occurring in public or private contexts, and the positionality of the writers, in order to disclose the discursive aspects of the production and circulation of images, metaphors and narratives that finally constitute our knowledge about historical figures, which also largely defines their reception from the past to the present.
\end{abstract}

Key words: history of folkloristics, life-writing practices, scholar of narratives, (self-)representation

In my contribution, I propose to discuss some aspects of narrative, or narrated, representation by combining life narrative, life-writing and investigation into disciplinary history, to illuminate certain moments of standing for or taking the place of someone not present or unable to stand for himself in the history of folkloristics. After all, the method in folkloristics is that of representation: in our research and academic writing we represent the groups or individuals whom we have encountered in fieldwork or in archival texts, and whose acts of communication and repertoire our studies present. 
My study focuses on one of the key figures in Estonian folkloristics and folk narrative research, Matthias Johann Eisen (1857-1934). The massive amount of folklore accumulated under Eisen's initiative reached about a hundred thousand pages and formed one of the pillars upon which the Estonian Folklore Archives was founded. During his long and active professional career as an educator Eisen engaged himself in collecting various genres of folklore, among which tale repertoire was most prominently represented. Eisen's life in the last quarter of the 19th century and the first decades of the 20th century correspond to the periods of Estonian cultural development, national awakening, and nation-building concurring with the gradual chiselling of disciplinary boundaries in the academe and the establishment of professional folkloristics around the Gulf of Finland, which is paralleled in Eisen's evolvement into an internationally known folklorist. Besides being a highly productive collector of expressive culture in narrative form, Eisen was also a prolific author and published numerous books, many of those based on the collected material. These tales and legends of folkloric background, or stories of historical events and people that he collected, penned and published, have become the representational

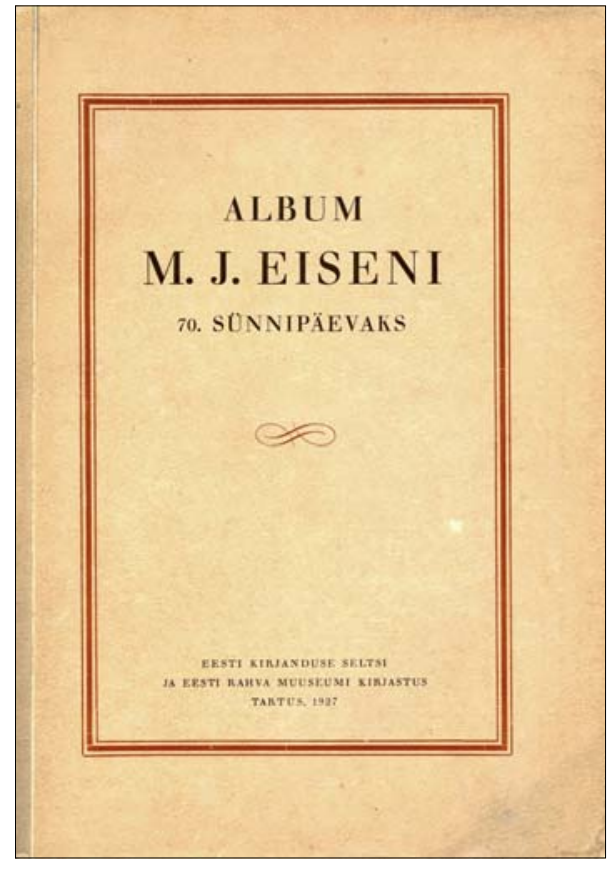

Figure 1. Album to Celebrate M. J. Eisen's 70th Birthday. Published in Tartu, 1927.

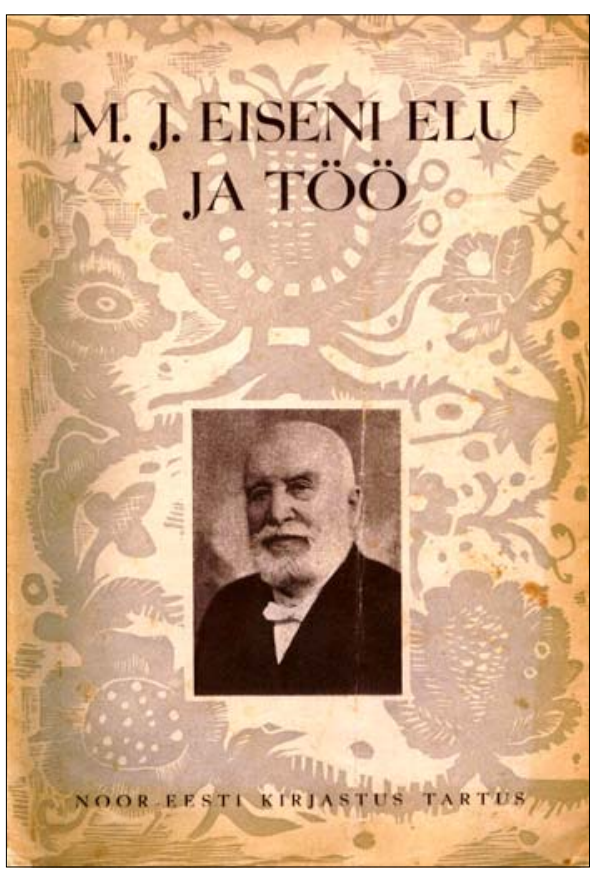

Figure 2. M. J. Eisen's Life and Work. Published in Tartu, 1938. 
image of Eisen. But I would like to expand the narrative repertoire that has defined his life with an analysis of narratives which represent this seminal cultural figure for posterity in biographical or autobiographical essays and memoirs. In this article my aim is to discuss Eisen's public and self-referential representation, where I will try to trace the portrayal in the making, based on publications and manuscripts engaged in constructing his life narrative. Eisen's published life-writing texts are available in Eisen 1921, 1925a/b, 1926, and 1931. The entire collection of Eisen's manuscripts - together with autobiographical material - is deposited in the Cultural History Archives of the Estonian Literary Museum. ${ }^{1}$ My study of his public representation will concentrate on two printed sources: a festschrift, to celebrate Eisen's 70th birthday in 1927, and a memorial volume published in 1938 to commemorate his 80th anniversary. When examining the material discussing Eisen ever since these publications, it becomes clear that anyone who has written anything substantial about him has basically relied on these two books for information about his life story, family and friends, or looked there for details about his professional career and colleagues.

\section{NARRATOLOGY, HISTORIOGRAPHY AND LIFE WRITING PRACTICES}

These books and Eisen's autobiographical writings, which have previously functioned simply as referential material to provide biographical data, attracted my interest for further examination in connection with a larger project that investigates the construction of the disciplinary history of ethnographic studies in Estonia. The study of the progress of academic folkloristics particularly in the early 20 th century from the perspective of reflexive cultural critique propounds to complement the investigation of ideas and methods in the intellectual history of ethnographic studies with other trends of inquiry prevalent in recent disciplinary histories, that is, to analyze the institutionalisation process of museums, learned societies, research institutions, universities, and to examine individual careers, scholarly networks, and schools of thought by studying biographies and autobiographies.

My examination of the academic and personal representation constructed of folk narrative scholars while applying a reflexive historical approach to the construction of narrative in life writing involves also a tacit agenda to map the ontological principles in the constitution of an academic discipline of narrative research, mostly from the overlapping perspective of narratology - perceived 
here as a general term for narrative theory - and historiography. The broader theoretical and methodological questions dovetail with the philosophical concerns of history writing, but also with the emergent generic strategies and narrative modes in biographical writing. The study of narratives and history writing have both been poignantly combined by Hayden White (1978) who advocates the fictionality of all historical narratives, to which we may well assume a parallel in biographical narratives. White argues that historical writing is interpretive, its argumentation involves a choice of paradigm, its tract requires choice of ideological perspective, and "historical narrative itself enjoins a choice of a plot structure, which [...] is related to the discursive tropes that 'figure' the writing of the text" (see Carroll 2001: 246). Historical narrative is a representational structure and metaphorical statement where the configuration of the past does not derive from events themselves, but is culled with the pre-existing emplotment strategies by the writer which are taken under more careful scrutiny in White 1992. In his narrativist philosophy of history, Frank Ankersmit furthers the narrative-as-representation argument by drawing attention to the retrospectivity of such presentations, while stressing the characteristic feature of narratives by calling them "pictures of the past". Ankersmit contends that "narrative interpretations are not knowledge but organizations of knowledge" (Ankersmit 2001[1983]: 241). Considering my specific perspective on the writings representing the past, where the ontological and epistemological contingencies are traced in the institutionalisation process of cultural disciplines and biographical progress of individuals, I suggest here a conceptual trajectory to the perception of constructedness and representational contingencies of the writing of life history or disciplinary history, for that matter. This perspective on narrative discourse combines a critical examination of historical representation with a reflexive analysis of individual portrayals created by selves and others in the process.

The descriptive essence of representational narration conveying events of the past is similarly outlined in the famous catchphrase by another philosopher on history, Louis Mink, when he claims that "stories are not lived but told" (Mink 1970: 557, but cf. also Mink 2001). In order to articulate a tangible link to the discussion of biographical narratives in the present context, this expressive quotation could be paraphrased by stating that "life stories are not lived but told", which clearly foregrounds the constructedness of life writing as a representation, similarly to the critique aimed at history writing.

An autobiographical or life narrative - as Sidonie Smith and Julia Watson propose to call it in their book Reading Autobiography - is "a historically situated practice of self-representation" that appears in the form of texts in which "narrators selectively engage their lived experience through personal story- 
telling" (Smith \& Watson 2000: 14). Autobiographies are not transparent accounts of experienced events or personal progress, but they are representational texts carefully constructed and outlined for an imagined reader. Though mostly conceived in privacy and left in manuscript form, they are nevertheless strongly influenced by the audiences imagined and envisioned by the writer. Autobiographical narratives reflect similarly intricate and complex practices of remembering as do biographical representations created by others. Thus the politics of remembering occurs in the public and the private context, is constructed about the person and by the person himself. Life narrative is located in a specific time and place, while the narrative moment is "in dialogue with personal processes and archives of memory" (Smith \& Watson 2000: 14). James Olney has particularly emphasised the role of memory in this representational process. He prefers the term 'life-writing' which particularly draws attention to the final product of the act of remembering to create an emergent representation of past events and experience in writing (Olney 1999).

In order to cover those various aspects inherent in historical life representations of individuals with seminal cultural clout, among them Matthias Johann Eisen, the current discussion proposes to extend consideration to the positionality of the writers reflected in the occasions of life-writing examined. It all serves the goal of drawing attention to the discursive aspects of the production and circulation of images, metaphors and narratives that finally constitute our knowledge about historical figures, which also largely defines their reception from the past to the present. Our knowledge of Eisen, and eventually his role in cultural or disciplinary history, is organised by the two books introduced above, by the occasions of life-writing reflected there. Besides these biographical representations, similarly instrumental in this representational process turn out to be his autobiographical manuscripts and published memoirs. These narratives authored by different persons have in sum created the discourse of Eisen as a man and scholar for posterity.

\section{EISEN'S LIFE STORY}

Matthias Johann Eisen was born in 1857 in western Estonia as a village schoolmaster's son. His childhood environment gave a strong impetus to his emerging cultural and intellectual interests. He learned to read and write at an early age (Eisen 1925a: 344), and considering his later engagement in folklore collection it is of interest that according to Eisen's autobiographical notes, his first attempt to document folklore occurred in $1869,{ }^{2}$ when he wrote down about a 150 riddles from schoolchildren attending his father's class (Eisen 1921: 195). 
The talented youth was sent to continue his education at larger urban schools on the western coast in Pärnu and in Haapsalu. There the instruction of students, regardless of their descent, was carried out in German, but Eisen remained true to his vernacular roots with the help of local teachers and intellectuals of Estonian origin who introduced Eisen to translating, to poetry and journalism, which kindled his writer's talent so decisively that he described himself later as having been "hypnotised by writing" (Eisen 1925a: 349). He published his first collections of poetry in 1876 and 1877, accompanied by several translations of novellas and tales of history from German and French. By the time Matthias Johann Eisen ${ }^{3}$ entered the University of Tartu ${ }^{4}$ in the autumn of 1879, he had published already about 25 booklets, mostly averaging about 50 pages, the thinnest comprising only 16 . The majority of them were translations and their subjects were often recent or more distant historical events.

Eisen's burgeoning interest in literary activities was supported by the general patriotic atmosphere that was predominant all over Estonia in the 1870s. This was a period of growing enthusiasm for writing and publishing in Estonian by those who were forced to switch to German as soon as they passed the elementary village school level, while the majority of literature available so far in Estonian had been predominantly edifying or religious. The national activism of the time automatically encouraged the production of reading material for the rising intellectual demands of its audiences. But what remains particularly significant is that from his schooldays onwards Eisen employed his quick pen and developed a habit of providing contributions for all kinds of publications in the Estonian language. ${ }^{5}$

In 1879, Eisen enrolled in the programme of theology at the University of Tartu where his public activism and literary activities gave way to more serious academic engagements. Nevertheless, Eisen entered the circles of patriotic Estonian students right away and accompanied his peers in several seminal undertakings of the day. The number of students of Estonian descent was apparently the largest in theology in the period. ${ }^{6}$ While extracurricular activism did not encourage timely completion of his degree, it led to Eisen's acquaintance with major cultural figures - among them Jakob Hurt, the initiator of an extensive folklore collecting campaign in Estonia - and cultural engagements, which continuously involved advancement in publishing and editing practices.

Among the more influential events of Eisen's student days that defined his future undertakings turned out to be a trip to Finland in 1881 to celebrate the 50th anniversary of the Finnish Literature Society as one of the official members of the large Estonian delegation. ${ }^{7}$ This memorable trip introduced Eisen 
to several of his later mentors and colleagues in the study of folklore in Finland, especially to Kaarle Krohn (1863-1933) who eventually made a tremendous impact on Eisen's folkloristic endeavours. This trip likewise launched Eisen's career in organising Finnish-Estonian cultural exchange.

In 1885, Eisen graduated from the University of Tartu, but finding a pastor's appointment in Estonia was not easy at the time for nationalist theologians,${ }^{8}$ and therefore his clerical career was launched via St Petersburg, which led to provisional appointments in the Finnish-speaking region of Ingria and Karelia, and eventually to a permanent position in Kronstadt ${ }^{9}$ from 1888 until 1912, where he served the mixed Estonian-Finnish-Swedish congregation in all those languages. In 1889, Eisen married Ella Petronius of Ingrian descent, a daughter of the Vuole provost and sister of his schoolmate from the Tartu days. Though her first language was Finnish, the couple eventually spoke Estonian at home. In addition to the Lutheran Nikolai (St Nicholas') Church in Kronstadt, pastor Eisen also took care of the Lutheran congregation of the Baltic Sea Navy based in this Russian naval port. He was engaged in pedagogical activities, teaching religion (mostly in Estonian, but occasionally also in Finnish and German) and the Estonian language at the elementary or high school levels for thirty-five years in total, from 1887 until 1922 (Roos 1938). In Kronstadt, Eisen had to operate under the more socio-culturally restrictive Russian rule as a minister in a church of inovertsy (Russian for adherents of foreign creed, cf. Ploompuu 1938: 66), where he served people of various ethnic descent, with the addition of men from the naval forces, while his free time and personal interests gravitated more to the study of Estonian folklore. Mostly due to his poor health, Eisen went on early retirement in 1912, after 25 years of serving as a minister in the damp climate of Kronstadt. When he resettled in Tartu, he continued teaching at various schools, and also worked for a shorter period of time at the newspaper Postimees. These were actually turbulent times in socio-political life: after the establishment of the independent Republic of Estonia in 1918 and the rise of the Estonian-language university in Tartu, Eisen was eventually recruited among the new faculty of the so-called Estonian national disciplines.

Matthias Johann Eisen was first appointed a Private Docent (eradotsent) in 1919 and later nominated Personal Professor (isiklik professor) to teach Estonian folklore in 1921 (Tampere 2000: 251). His classes ranged from introductory courses in the field to comparative studies of Estonian and Finnish folk songs and national epics, and to customs, beliefs, and studies of mythology. Eisen was engaged in full-time teaching until his official retirement in 1927, but even then he continued to lecture occasionally. In total his university career extended to a full 15 years, with 30 semesters of instruction (Tedre 1995: 
165). He was an energetic participant in the Tartu academic and cultural life. Eisen founded the Academic Folklore Society in 1925; he was elected the Chairman of the Council of the Estonian National Museum in 1920, which comprised Eisen's participation also in the seminal arrangements to institute academic studies in ethnology in Tartu, both at the museum and at the university (see Kurrik 1938). He also served as the chair of the Archival Library there for ten years. At the period of Eisen's chairmanship, the National Museum moved to the new impressive facilities at Raadi Estate and a separate building was purchased to house the Folklore Archives.

Eisen was recognised as a prominent nestor of Estonian socio-cultural activities that extended from the national awakening to the building of independent Estonia's cultural foundations. To honour his significant contribution to his nation and to international cultural exchange, Eisen was awarded the title of doctor honoris causa by the Faculty of Philosophy at the University of Helsinki in 1927, while the Finnish government decorated him with the Order of the White Rose the next year. The Faculty of Theology in his own alma mater awarded him the honorary doctorate in 1932. Matthias Johann Eisen died in Tartu in 1934 at the age of 77.

\section{REPRESENTED LIFE AND NARRATIVE RESEARCH}

In the following I will examine the two books that render a representation of Eisen by his contemporaries, in order to analyze the image created both in the academic and a more personal context, and to take a look at how he is framed in these immanently celebrative volumes. At the same time, these two books provide a concise overview of the scholarly interests prevailing in the day with some reference to the practices of narrative research, but they also extend to sharing light on the socio-cultural atmosphere and intellectual life in Estonia over the period of a quarter of a century. That vast time-range bridges two centuries, in the course of which the position and circumstances of Estonian intellectuals made a tremendous transition from subservient oppressed circles into the representatives of independent national culture. At the same time it parallels the process of transformation from collecting modernisation-threatened peasant antiquities into founding the basis for burgeoning Estonian national culture in the institutionalised archives of age-old verbal lore.

The festschrift from 1927 comprises about a 170 pages, with the majority of the 13 articles presenting scholarly research by folklorists, linguists and ethnologists from Estonia and Finland, while the main topics discussed appear to be guided by an attempt to reflect the range and focus of the scholarly inter- 


\section{S I S U KOR D}

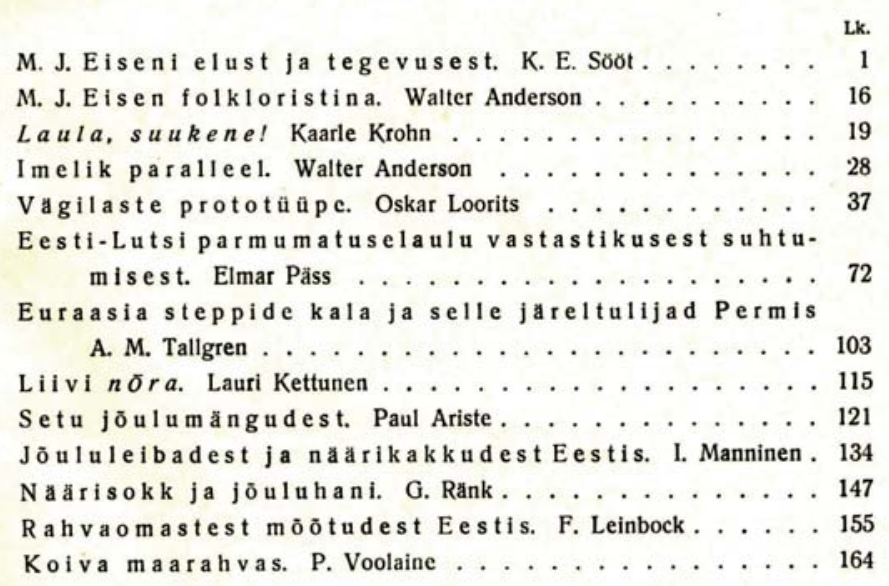

Figure 3. Table of Contents. Festschrift to celebrate Eisen's 70th birthday (1927).

ests of Eisen himself (cf. Album 1927). It seems that the authors have kept his academic contributions in mind when choosing themes suitable for such an edition, although they definitely show the areas of research current at the time and engaging to the writers contributing. The collection includes all in all 13 articles by an impressive list of scholars in the field. Walter Anderson, professor and chair of folkloristics at the University of Tartu gives a short summary of his colleague's role as a folklorist who collected and edited for publication unparalleled, vast amounts of narrative material. Anderson has also authored a research article and discusses the dissemination of a widely known Estonian folksong to which he found an amazing parallel in an Ossetian folktale. Kaarle Krohn, the major figure in the history of Finnish folkloristics, who was also well-versed in Estonian poetic lore, has contributed a comparative historical-geographic study of a folksong known around the Gulf of Finland. Both folklorists refer to Eisen's collection in which they have found these folklore items represented. Oskar Loorits, another famous Estonian folklorist, who had only recently entered the ranks of his older colleagues and former professors, publishes a lengthy study on the emergence and origins of folk legends of giants by searching for prototypes to these narratives. A note at the beginning celebrates Eisen as "the giant of Estonian folklore", alongside with Jakob Hurt 
(Loorits 1927: 37). Elmar Päss, Eisen's student and assistant, has provided a detailed dissemination chart of a children's song in southern Estonia and in Estonian communities in Latvia, in the neighbouring regions in Russia, and in the Ukraine. Two scholars from Finland who both worked as professors at the University of Tartu, have written comparative studies of Finno-Ugric material: the archaeologist Arne Michael Tallgren and the linguist Lauri Kettunen, whose articles tackle a Permian fish-shaped pendant and the debated origin of a poetic adjective in the Livonian language, respectively. The young folklorist and linguist Paul Ariste discusses the Christmas games of the Setu that he had documented at fieldwork. The collection also presents articles by ethnologists, first among them being another representative of the academic bridge between Finland and Estonia, Ilmari Manninen, who analyzes Christmas breads baked in Estonia. The other one is by the then novice Estonian ethnologist Gustav Ränk who examines Christmas customs of mummery, while both refer to Eisen's research on Estonian mythology. The last contributions are by Ferdinand Leinbock $^{10}$ on popular measurements and their terms in Estonian, and by Paulopriit Voolaine who introduces the Estonian settlement on the Koiva (Gauja) River in northern Latvia. This is a truly academic volume with many representational scholarly articles by Eisen's younger colleagues, clearly composed with a set goal of instituting academic authority. ${ }^{11}$

The first contribution to open the festschrift is, however, a short biography of Eisen which precedes the research articles and gives the whole volume some personal focus. These 15 pages were provided by a poet, journalist and publisher Karl Eduard Sööt (1862-1950), of Eisen's generation of the late 19thcentury Estonian intellectuals with whom he shared creative interests and cultural activities. ${ }^{12}$ Sööt was a respected figure in the Estonian-language sociocultural life, but he was not academic, which is an interesting fact that probably testifies to Eisen's noticeable leverage among the Estonian society with wider outreach than the strictly scholarly circles. This is a relatively matterof-fact and lucid narrative, which resorts to a respectful distance and remains an introduction of biographical facts that present the crucial moments or career turns, and a reference to the major publications by Eisen. Sööt is quite open with revealing his sources by quoting them directly and letting the reader know that he has drawn his knowledge on Eisen's life and career mostly from previously published autobiographical writings (Sööt 1927).

The memorial volume M. J. Eiseni elu ja töö ('The Life and Work of M. J. Eisen'), published four years after his death in 1938, is quite different in its structure, in the variety of contributors included, and apparently also in its expectations for the reading audience. ${ }^{13}$ The book has a prominent beginning that reflects particular socio-cultural authority, when writings of Eisen's life 


\section{SISUKORD:}

Johan Kõpp: Saateks

I. M. J. Eiseni eluloost.

1. A. Looring: M. J. Eiseni vanemad, noorpōlv ja kooliaastad. . 11

2. F. W. Ederberg: Matthias Eisen üliōpilasena. . . . . 37

3. F. W. Ederberg: M. J. Eiseni rännuaastad. . . . . . 58

4. A. Ploompuu: M. J. Eisen Kroonlinna õpetaja $(1888-1912) . \quad 66$

5. Jaan Roos: M. J. Eiseni pedagoogiline töö. . . . . 78

6. Elmar Päss: M. J. Eiseni õppetööst Tartu ülikoolis. . . . $\quad 87$

7. H. B. Rahamägi: Isa Eisen ülikooli koguduses ja kirikus. . 93

8. F. W. Ederberg: M. J. Eisen emeeritusena Tartus . . . 100

II. Mälestusi M. J. Eisen ist.

1. Aleksander Mäevälja (Mohrfeldt) †: M. J. Eisen eesti elu arvustajana.

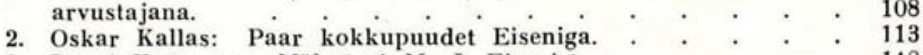

3. Lauri Kettunen: Mälestusi M. J. Eisenist. : ${ }^{*} \cdot{ }^{*} 118$

4. Samuel Sommer: Minu mälestusi prof. M. J. Eisenist kui 120

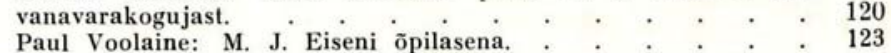

III. M. J. Eiseni töö ja harrastus.

1. K. E. Sööt: Märkmeid luuletaja loominguteilt. . . . . 125

2. Walter Anderson: Eisen ja Hurt rahvaluulekogujaina. . . 130

3. Elmar Päss: Eiseni rahvaluulekogudest. . . . . . 133

4. Elmar Päss: Eiseni enese rahvaluule-kirjapanekuist. . . . 140

5. Elmar Päss: Eiseni rahvaluuletrükingute süsteemist. . . . 145

6. Paul Ariste: M. J. Eisen nimedeuurijana. ..${ }^{*} 161$

7. Richard Antik: M. J. Eiseni raamatuharrastus ja raamatukogu. 163

8. K. E. Sööt: M. J. Eiseni a jakirjanduslikust tööst. . . . . 167

9. Villem Ernits: M. J. Eisen hõimutegelasena. . . . . . 174

10. Helmi Kurrik: M. J. Eisen ja Eesti Rahva Muuseum. . . . 179

11. A. Looring: M. J. Eisen karsklasena. . . 185

12. Elmar Päss: Lisandeid M. J. Eiseni bibliograafiale. : . . 191

IV. $\mathrm{L}$ is a.

1. Alma Päss: M. J. Eiseni sugukonna tabel. . . . . . 215

Figure 4. Table of Contents. Memorial album on M. J. Eisen's life and work (1938).

and work are garnished with an introduction (Saateks) by the rector of the University of Tartu, a theologian and historian, professor Johan Kõpp ${ }^{\mathbf{1 4}}$, and with a final appendix (Lisa) that presents a genealogical chart of the Eisen family, which dates back to the 17 th century. Such framing renders to the volume a certain atmosphere of closure and respectable scope of the role and impact of the person celebrated in this edition.

The book is divided into three larger sections: 1) about Eisen's life; 2) Eisen reminisced; and 3) Eisen's work and interests. The fourth is the appendix referred to above, on a separate sheet. A note attached informs the reader that the book was planned to commemorate Eisen's 80th birthday. The general 
ambiance that this volume radiates is deep respect and a tacit mission to paint a relevantly colourful and illuminating portrait for the wider audience: this was a man who served his people for more than half a century, his greater goal was to further and promote spiritual values among Estonians, but also to return their ancient heritage to them in his publications (Kõpp 1938: 10). It is highly celebrative, occasionally rather emotional, up-lifting and awe-inspiring representation of a versatile man with a long and active career in public service. The aim of the overall picture is to reconstruct the progress and significance of a seminal public figure through detached or more personal narratives that are penned by his contemporaries, friends, colleagues or students who are gathered between these covers to tell about all the possible fragments of historical interest that compose a life story, a passage and progress of a man.

The first section, titled under life story, includes eight separate contributions: about Eisen's parents, childhood and schoolyears; his activities as a university student; his travelling years; period in Kronstadt as a minister; his pedagogical work; his career at the university; Pastor Eisen and the university congregation and church; an emeritus in Tartu. The second section of 'Memoirs' introduces Eisen as a moral critic of the Estonian society with a powerful edifying purpose to strengthen the national spirit, which is likewise praised by his former student Voolaine and an amateur folklore collector Sommer who got greatly inspired by Eisen's encouragement. Enclosed are also collegial memoirs by the folklorist and diplomat Oskar Kallas (1938), for whom the senior intellectual had been inspirational in his keen interest in collecting and promoting literature in the Estonian vernacular under the difficult circumstances of Russification and Baltic-German domination. The other author of memoirs is the linguist Kettunen, who appeared already in the previous volume.

This second publication discussed in the present article, the memory album, has increased its representative capacity also with a powerful visual image: the book presents more than 30 photos of people, places and occasions significant in the particular life story recounted. A parallel visual representation does occur in the first publication, but it is basically limited to the first biographical piece while other photos in the scholarly articles understandably illustrate the examined topic. Photos of Eisen's mother and wife together with portraits of the celebrated scholar in the earliest stages of his career, included already in the first book, render some personal touch also in the second volume. But the visual scope is expanded and varied to introduce sites and people, mostly from his youth and later years. The introductory biographical articles are illustrated with several buildings to signify certain milestones in Eisen's educational progress (see Looring 1938a, Ederberg 1938a/b, but also Ploompuu 
1938). In the overall representation of the first section, the reader gets well acquainted with his school years in various locations, where his interest in books, languages, translation, poetry, narratives, and folklore collecting took shape. We learn about who his fellow students were and what kind of activities were included in the nationalist-inclined Estonian student life at the Dorpat University, then dominated by Baltic Germans but under the administrative rule of the Russian Empire, but we are also given an overview of Eisen's busy working years as the Lutheran minister of Estonian, Finnish and Swedish congregations in Kronstadt. These aspects of his career are wrapped up with a recount of his return to Tartu, and the trials and tribulations connected with the building of the independent Republic of Estonia.

The memory album - with the illustrative elements attached serving the same purpose - prominently extends the printed representation of Eisen's life narrative to all the professional and social roles that he had carried out with impressive results, which the authors of the contributions highlight with striking poignancy and emotion in many cases. Such manifestation of emotion and personal attachment - which may even appear vexing to the modern reader in search of biographical facts - can be, in a way, explained by the original occasion for writing these texts as some of these were part of the actual funeral service. Among those belong obviously the overview of Eisen's contribution and service to the university congregation, narrated by Bishop Rahamägi (1938). While in the festschrift Eisen's career as a pastor was rather toned down (with no contributions by the representatives of the clergy at all), then in the memorial volume the clerical presence is quite significant in rank and volume. This second volume also introduces in greater detail his work as a schoolteacher,

Figure 5. Eisen with his bound and archived folklore collection in 1932. Estonian Literary Museum (EKLA A-27: 5933).

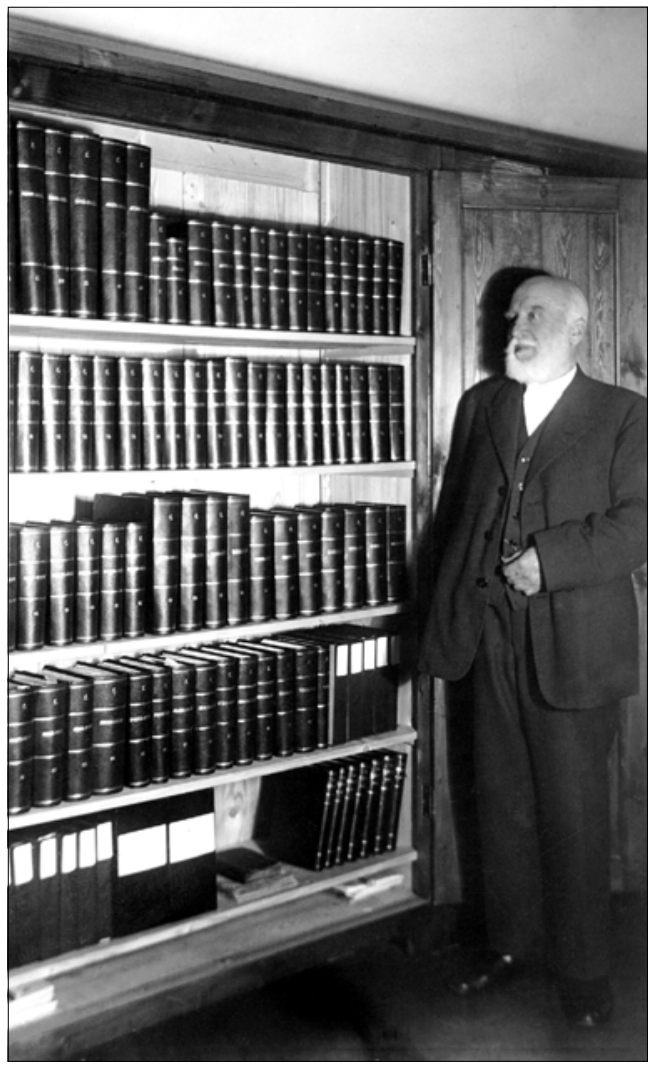


and as a temperance activist (Looring 1938b); we get a greater insight into his bibliophile activities (Antik 1938), his participation in volunteer associations, but also into his work as a university professor, scholar and collector of folklore (cf. Päss 1938a-e). In that respect, the first section of the edition is inherently linked to the third one, with the subtitle 'Work and Interests', while it seems understandable that the authors (and editors) have found it difficult to draw here a clear distinctive line. At the same time, the third section is dedicated to the roles in Eisen's life that carried the widest public weight.

Eisen's contribution in the latter field that focused particularly on folk narratives, led to a massive amount of documented folklore, which eventually formed a solid basis for the establishment of the Estonian Folklore Archives. He started his organised collection in the late 1880s, but having left Estonia by that time to seek a pastor's position near St Peterburg and in Kronstadt, he relied on the help of local enthusiasts who responded by correspondence to his appeals published in Estonian newspapers. The long decades of such collection activities eventually gathered about a hundred thousand pages of tales, proverbs, riddles, songs, etc. (Päss 1938b: 135). Narratives yielded the largest percentage and Eisen considered it his duty to return the narratives to the people in printed form as his publishing endeavours were inspired by an edifying ideology: he encouraged the Estonian reading audience to become more interested in their national history while collecting "old gold" into national treasuries, and to expand their Estonian-language libraries at home with this valuable repertoire (Eisen 1921: 202). Starting mostly in the 1890s, Eisen produced small popular books of narratives that comprised aetiological legends, legends and fairy tales, popular jokes, and collections of tales of supernatural beings, and tales of mythological background. These editions became immensely popular and widely disseminated, ${ }^{15}$ they were relatively cheap and accessible, written in poignantly "folksy" narrative style. This corresponded to Eisen's editing principles while he arranged and changed the wordings of the original stories for publishing purposes. Besides these folklore collections, Eisen translated or penned several publications of tales on historical events at home and abroad, travel accounts, biographical narratives and popular fiction. By creating thus great amounts of popular literature printed in the Estonian language, Eisen actually functioned as a storyteller for his eager audience.

However, particularly the issues mentioned here, Eisen's publications of folklore material, his collection principles and his contribution to academic research had given rise to criticism of the new generation of professional folklorists in the 1920 s and $1930 \mathrm{~s},{ }^{16}$ which find a manifested reflection in at least two contributions to the 1938 memorial album. Both Walter Anderson and Lauri Kettunen present a sort of rehabilitation of Eisen's significance as a 
folklorist, to which are added three thorough surveys written by Elmar Päss on Eisen's collection work, documentations and publications of folklore (Päss 1938b-d). Paul Ariste (1938) has added another research aspect by discussing his interest in Estonian proper names. The vast scope of the passed nestor's import to Estonian culture is expanded in the rest of the contributions as well: in this volume, Karl Eduard Sööt (1938a/b) paints a portrait of Eisen as a poet and a journalist; other authors illuminate his role as a bibliophile, an activist of the cultural exchange among Estonians and Finns, an active advocate of the temperance movement, and his functions on the executive board of the Estonian National Museum. Eisen's work and interests are wrapped up in the final contribution of this album section, provided again by Päss (1938e): an exhaustive bibliography of Eisen's published writings that includes 761 items.

In order to return to a more focused discussion of life-writing practices, let me sum up this overview by pointing out that the number of contributions in the memorial album M. J. Eiseni elu ja töö narrating various periods of his life is eight in total, comprising half of the book. His youth and clerical career fall under biographical section, while the majority of material connected to his folklore activities appear in the third section introduced above. Such representative choice was apparently made by the editors and most productive contributors to the memorial: Friedrich Wilhelm Ederberg, Eisen's peer from his student years in Tartu, pastor and provost emeritus, together with Elmar Päss, Eisen's student at the university and young colleague in folkloristics. They defined the historical organisation of knowledge, picked out pictures of the past and administered the emplotment (see Ederberg \& Päss 1938).

This whole volume is in essence a collection of memoirs, but the scale of detail or intimacy with the knowledge shared varies from article to article. The most standard texts in their approach to describing past events and the actions of historical persons are rendered in the personal memoirs of the author of a particular contribution. At the same time, the longest passages of Eisen's life story provided by pastor Ederberg and cultural historian Aleksander Looring were quite fascinating in their capacity to introduce the reader into phases of Eisen's progress with amazing precision in describing various occasions, particularly in his childhood and youth. It seemed as if the narrator had to be present at most of these events to provide such fiction-like detailed narratives, especially for the earliest period in Eisen's life. While Looring (1938a: 36) gives a brief list of his sources, Ederberg makes no such reference, relying perhaps on his personal attachment to the celebrated man that might automatically grant him access to relevant knowledge, which at the same time strongly influences the atmosphere of the representation published in this memorial volume. 


\section{NARRATED LIFE BY NARRATIVE SCHOLAR}

From the perspective of the creation of a public representation by others and the project of biographical texts, I will shift to the production and agenda of self-representation which is traceable in autobiographical writing. In Eisen's case we would have to look at both published and unpublished material, which draw an interesting parallel to his principles and style in the management of written text as a narrative scholar.

While Ederberg had left his sources unspecified, one can nevertheless trace them in the whole corpus of Eisen's self-representational life-writing, regardless of their shared experience and personal memories, because in comparison, the narrative design, the narrator's position and choice of events coincide to a great extent. ${ }^{17}$ Eisen's first article that chronicled his progress into a collector of folklore was published in Finnish in 1921 in Kalevalanseuran vuosikirja, the yearbook of the Kalevala Society under the title 'Miten minusta tuli kansanrunouden kerääjä ja Kalevalan harrastaja' ('How I became a collector of folklore and an enthusiast of Kalevala'). In 1925, Eisen published two pieces of memoir writing in the journal of Estonian literature, Eesti Kirjandus, first "Kuidas ma kirjameheks sain" ('How I became a writer') which was complimented with an extensive bibliography of the books and articles published from 1876 till 1925. This article rendered a detailed narrative recounting his first steps in reading and writing that became later focused on the early progress in translation, fiction and journalism (Eisen 1925a). The second article, 'Killud ja dokumendid. Kuidas mind ajakirjandusest eemale tõrjuti' ('Pieces and documents: How I was overruled in the press') described his experience with journalism as a schoolboy in 1876 (Eisen 1925b). These contributions to the edition of the journal appeared with an overall goal to celebrate a writer's career that had extended to 50 years. ${ }^{18}$ In addition, he published two memoir articles on the cultural exchange and friendship between Estonian and Finnish intellectuals since the 1880s, in which Eisen had played a significant role (see Eisen 1926 and 1931).

These articles that are available in printed form have actually a fascinating parallel deposited in the archives, which in this case does not denote a previous working copy of an eventually published text. Other versions of these narratives can be found in the manuscript life narratives written by Eisen and stored at the Estonian Archives of Cultural History. ${ }^{19}$ My plural in narratives here is intentional: Eisen's approach to the genre of autobiographical or memoir writing was creative, and in his case it is impossible to make a distinction between the two either in published or in unpublished texts. He wrote several narrative versions of certain periods and events that he had experienced. His 
files include four thin booklets of 60 pages in total, where pages filled with neat and economising handwriting are joined under the cover inscription 'Eluloolisi andmeid' ('From my life story'). In these texts I could recognize the originals of the detailed and intimate descriptions that had puzzled me in the memorial volume where such reference was missing or was rather misleadingly inconspicuous. In the public biographical representation of Eisen, the authors who recounted different passages of his life had adopted Eisen's voice, but they had carefully re-tuned it by providing continuity, coherence and closure that is usually characteristic of life-writing as a representative biographical account. However, that did not exactly coincide with Eisen's personal style of narration.

Based on the archival files, one cannot exactly determine the sequence of writing of these autobiographical texts. The booklets do not indicate particular dates for their writing, and probably due to rearrangements in the deposit system of the archive, the booklets and loose sheets have been repaginated a couple of times. At the same time, the storyline does not run in an ordered progression from the most distant past to recent times, but makes temporal twists and turns. The author of these writings has not set a goal of creating a chronological narrative, but seems keener on introducing and explaining certain experience or developments that have defined this particular life story from the perspective of the narrator's present. Thus it is impossible to settle the order of writing for each and every passage, yet that does not automatically mean that the story told appears to be without structure. Judging by the topics discussed or opinions expressed, some of these retrospective narratives seem to have been written in 1925, but others indicate reference to later years when lists of events and public appearances often end with the year 1927 when Eisen was appointed emeritus, and most probably fall to his full retirement in the early $1930 \mathrm{s.}^{20}$ The story includes an impressive account of the celebration of his 70th birthday where among the guests and colleagues appear many dignitaries of the day.

Eisen's own investment in an effort to create coherence and closure is reflected in his repeated and refurbishing returns to some particular events or years. The largest booklet that makes up half of the manuscript volume actually manages to recount only his first 30 years. The narrative starts with a detailed account of his birth (see Fig. 6) and continues with a thorough introduction to his parents. The recounting of school experience gives years of entry and some memorable moments, with reference to the later callings in his life. Thus the narrator tells about his initial steps in writing and collecting folklore, but provides also hindsight reflections on his attempts at creative poetry. He dwells on the influential moments of listening to folktales and the emergent love for stories, and the contemplations eventually develop into a 


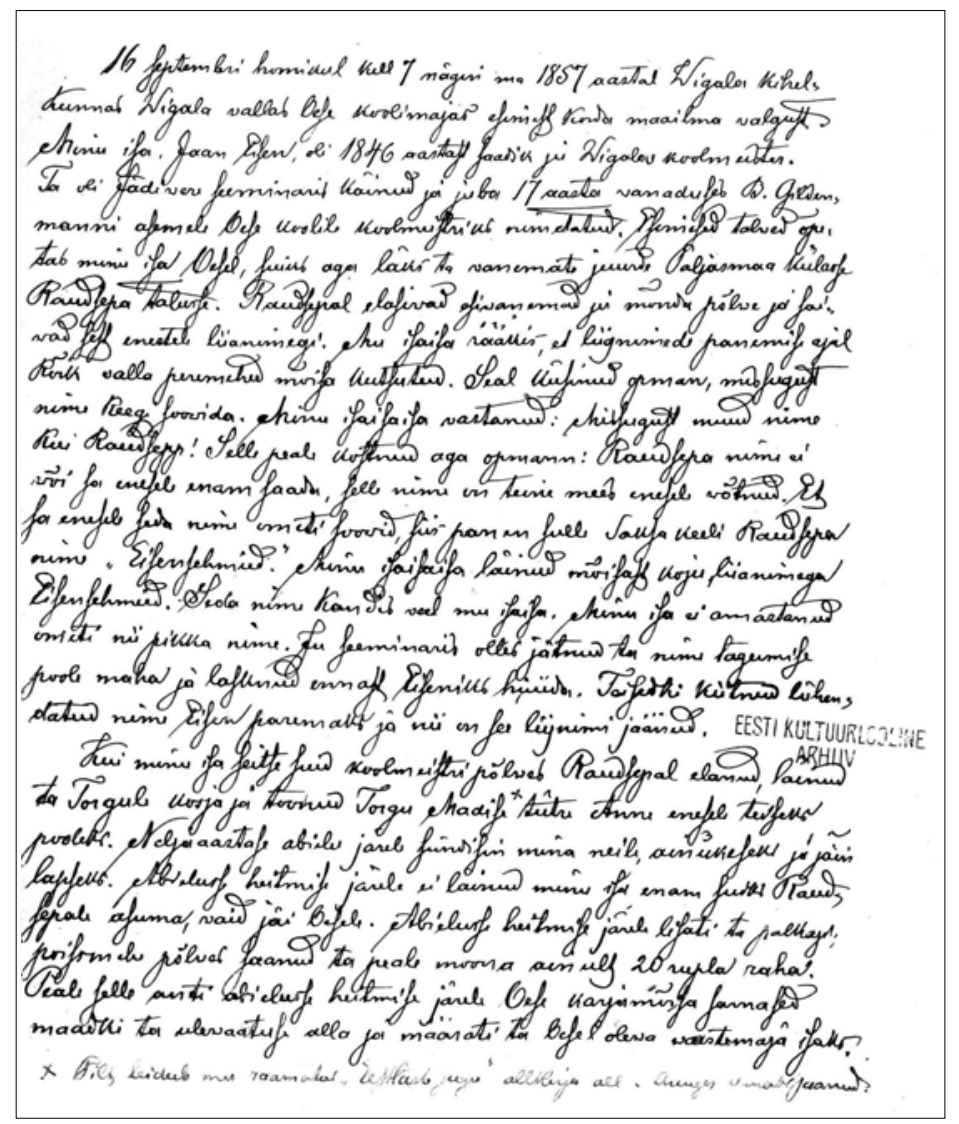

Figure 6. "In the morning of Sept 16, 1857 at 7 am in the parish of Vigala..." A page from Eisen's autobiographical manuscript. Estonian Literary Museum (EKLA f. 24, m. 28: 14, 1)

rationale for becoming a publisher and scholar of narratives. His interest in writing, poetry and printed text is reflected also through his telling about the student years in the late 1870s and early 1880s, including the highlight of meeting with Finnish students and scholars both in Estonia and on his initial trip to Finland. This intact narrative sequence ends with an account of the next stage of his life, the complicated passage in landing an incumbency that took him to the neighbourhood of St Petersburg, which had more opportunities for a young patriotic Lutheran pastor of Estonian background than would have been available inside the borders of Estonian provinces. Another significant experience tacitly involved into the encounters and ordeals described is the story of his courtship and eventual marriage to Ella Peronius from Ingria.

In the next few pages Eisen comes back in more detail to his earliest schooldays, but then leaps again to the incumbency ordeal and travels to and 
from St Petersburg, Ingria and further in Karelia during the period from 1886 to 1889 , which eventually ended with his ordination at Kronstadt and wedding. However, this topic has not been exhausted yet. In the following ten pages, he returns to discuss a different aspect and people encountered during that incumbency ordeal, starting from the year 1887. In the final pages of that particular booklet, a visibly distinct new section gives another reflexive deliberation on his personal progress into becoming a writer. Eisen has thus taken the effort of creating coherent, dialogic narratives of particular highlights and memorable moments. What seems apparent is his intentional writing to an audience; he presupposes a wide range of eventual readers to this unpublished texts. The narrator seems to come back to certain events and people in his life, in order to provide the reader with a more thorough picture of the things that have passed but might share a light on later developments.

The rest of the three smaller booklets covers also later periods of his life, though in comparison to the narratives recounting his younger years, the general approach to his later career and progress could be characterised by a remark that introduced the passage of more than two decades: "Life in Kronstadt was stable and 'uneventful' with each year resembling the previous one". ${ }^{21}$ He gives the basic facts and describes a few situations that provide the general idea of his work and responsibilities, but the majority of the 15 pages covering that period tell about his travels abroad, usually to improve his health and have a rest (e.g., in Marienbad, in Berlin, and in Finland). Eisen also recounts the disruptive events of the 1905 revolt in Kronstadt and St Petersburg, when he puts down the developments that he had witnessed in person. His interest in events with wider historical and social impact are reflected also in longer narrative passages that appear under separate titles 'Minu kokkupuutest enamlastega' ('My encounters with bolsheviks') and 'Okupatsioni aeg ('The period of occupation') which document his experiences in Estonia around 1917 and 1918, when Eisen worked at the daily Postimees.

An interesting aspect in Eisen's practice of life-writing is the significance of visual representation, both in the manuscript text and in the content of his self-portrayal that he finds necessary to leave for the posterity. The latter appears as an exhaustive account of the visual images made of him, though the later period of his life is represented in greater detail. He describes the creation process of the portraits that famous artists painted of him. But he has also documented the date in 1923 when his photo portrait was taken at the Parikas Studio, with an additional note that this photo was distributed as a postcard. That same visual image has been the most disseminated one and appears prominently in both of the books published in his honour (see Fig. 2). 
In Eisen's approach to narrative sequence, the most significant periods fall to the very beginning and the most recent years of his life; the years in-between get covered more scantily and usually in the form of a hindsight commentary. But in this management of memories that are transformed into text, Eisen actually parallels his activities as a narrative scholar in a most interesting way. He has recounted the nodal points in his life cycle, but has returned to the same experiences several times, to enlarge and expand the variants of the same narrative. His childhood, youth, and the period around his marriage with its incumbency ordeal have needed detailed accounts more than once. But even if we learn about the later years in a more fragmented way, the

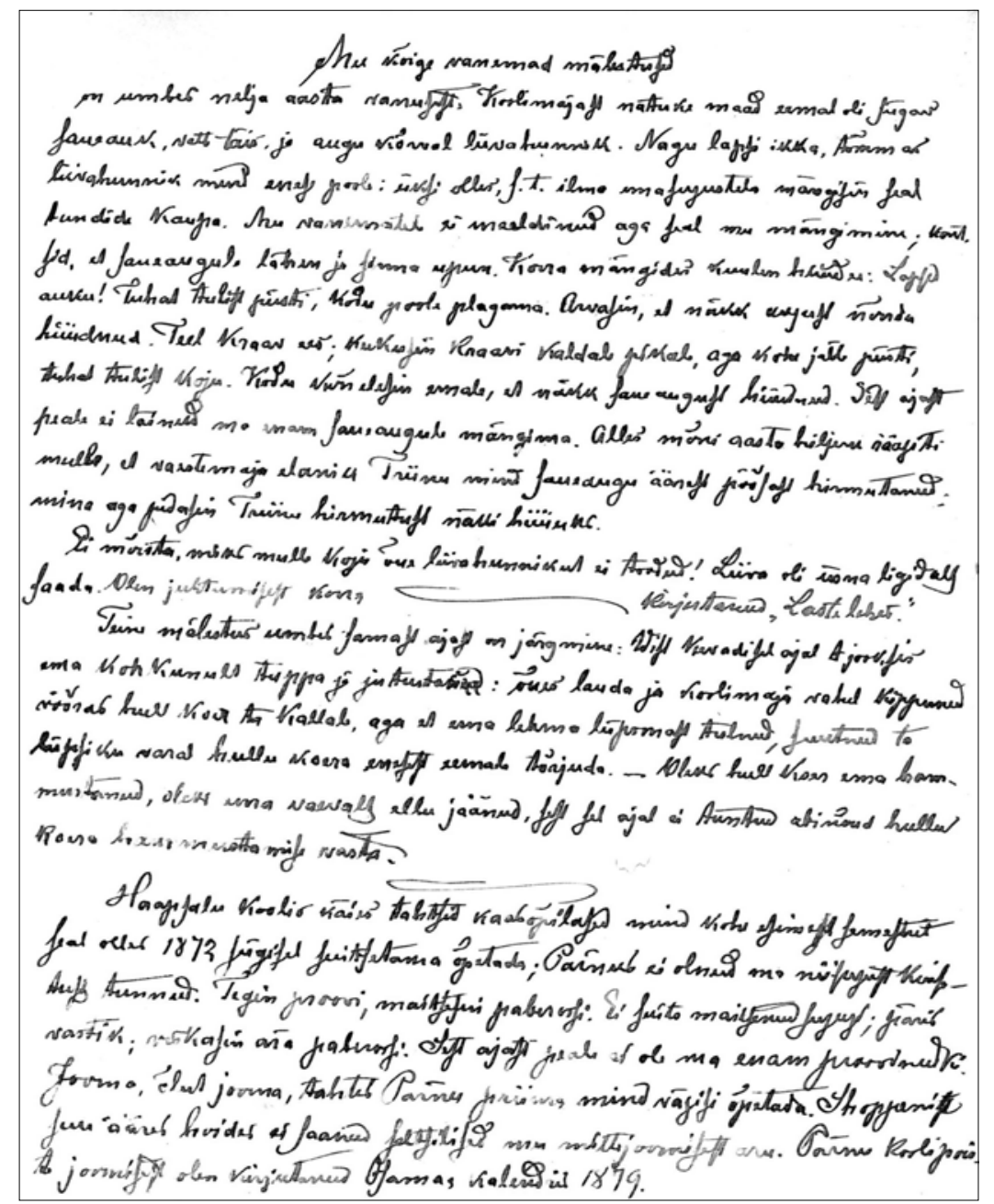

Figure 7. 'My earliest childhood memories.' A page from Eisen's autobiographical manuscript. Estonian Literary Museum (EKLA f. 24, m. 28: 14, 1/6) 
memorable moments presented have materialised in a complete, concise manner in separate passages. The events or persons described form neat narrative passages, with a beginning and an ending. Eisen seems to have been quite careful in the organisation of textual space in his narratives that can be seen also in the copies of the manuscript pages (see Figs. $7 \& 8$ ). Besides breaking the paragraphs with a curved line, the textual narrator has made the grasp of the structure and sequence of these fragmented short narratives easier for the intended reader by including subtitles to different themes: ' $M u$ kirjavahetus' ('My correspondence'); 'Mu kõige vanemad mälestused' ('My earliest memories'), 'Hädaohtlikud olukorrad' ('Dangerous moments'), etc.

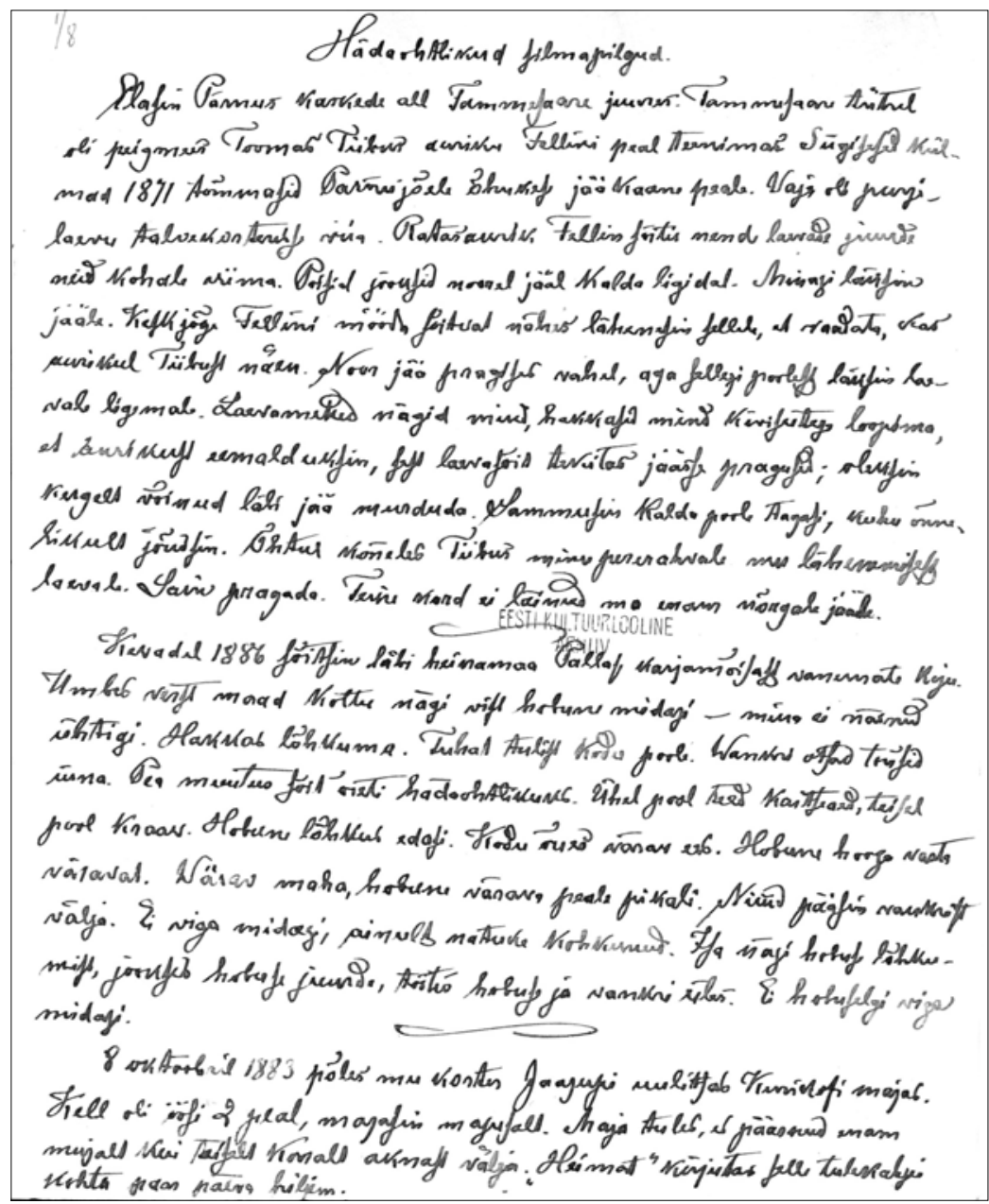

Figure 8. 'Dangerous moments.' A page from Eisen's autobiographical manuscript. Estonian Literary Museum (EKLA f. 24, m. 28: 14, 1/8) 
In conclusion, Eisen has constructed his life on paper by focusing and repeatedly returning to certain events of apparently special importance to him. His overall narrative is rather fragmented in structure, though, and inconsistent in plotting (with incommensurable constituents of experience, reflection, relationality and agency). However, he seems to be amazingly consistent in his general narrative mode that reminds poignantly of his published collections of folk narratives. For example, his life narrative passages have acquired similar structure and style with his collected and published aetiological legends, where one can find titles like 'Kust Vooremägi on saanud' ('About the origin of Vooremägi hill'), or 'Kuidas Pärnu kaupmehed rikkaks saanud' ('How Pärnu tradesmen became rich'). ${ }^{22}$

For Eisen, his lifestory is also a narrative that requires a reader, and not just one person, but a reading audience for whom a life narrative is constructed in a comparatively similar manner to the tales and legends that Eisen collected and published in order to re-circulate them and expand the reading repertoire for Estonians. Thus the self-representation of Eisen emerges as a life experience that is told as a story, or versions of a story, by a storyteller. In his life-writing practices, Eisen provided the imagined audience with different variants of the same story by varying and adding details, while it seems that the new variants, and even new stories, were triggered by particular moments that the narrator had included in the story told. This often characterises storytellers in their choice of topics for their next performance, whereas the same construction of representation was likewise observable in Eisen's published biographies, in their partial narratives and rhetorical aims.

One final puzzling observation: Eisen's self-referential manuscript life-writing reflects very little of his folkloristic activities, where an explanation might be to suggest that he perhaps felt that he had published enough on the topic already. In his autobiographical manuscripts appear references to his first contacts with folklore research, and meetings with his colleagues in Finland (the most influential among them being Kaarle Krohn). ${ }^{23}$ But he does not really elaborate on his decades long practices of folklore collection and narrative research, leaving that passage in his life relatively undisclosed. At the same time, we may actually glean more ontological information on the disciplinary history, on collegial relationships, friendships, academic inspiration, collaborations and feuds much more vividly in Eisen's archived personal correspondence. However, that would be an extensive topic on another aspect of lifewriting, which would require a separate study. The present investigation focused on particular volumes and a set of manuscripts of representational nature that provided an insight into the socio-cultural complexities and discur- 
sive practices in creating variants of life narratives of an Estonian scholar engaged in narrative research.

\section{ACKNOWLEDGEMETS}

Research for this article was supported by Estonian Science Foundation Grant No. 5964. An earlier version of my study was presented at the 14 th World Congress of ISFNR in Tartu, 30 July 2005.

\section{NOTES}

${ }^{1}$ With the archival reference EKLA, f. 24, m. 28: 14.

2 Apparently in connection with the first Estonian national song festival (Looring 1938a: 19).

3 The story of Eisen's name reflects the upwardly mobile tendencies of the time that suggest possible shifts in (national) identity: being baptized Maddis, he adopted the first name Matthias at school in Haapsalu; the most frequent form that appears in scholarly references 'M. J. Eisen' appeared only on the title page of his books with no explanation on the ' $J$ ' (cf. Looring 1938a: 14; Ederberg 1938a: 37). In his manuscript autobiography, Eisen has referred to the name Jaan, which had been his parents' first choice, in reference to family tradition (EKLA, f. 24, m. 28: 14, 1). Maddis and Jaan are Estonian equivalents for Matthias and Johann.

${ }^{4}$ Dorpat in German.

5 Eisen's bibliography includes 250 separate publications and about 500 articles (cf. Päss 1938b).

6 It should be pointed out that when the period of Russification was launched with Tsar Alexander III ascending to the throne in 1881, this academic programme was actually among the least affected by the disastrous cultural policies that affected this westernmost university, where Baltic German faculty and their ideological orientation predominated.

${ }^{7}$ Eisen was also the editor of the anthology of Estonian poetry that was officially presented to the Finnish hosts.

8 The Baltic German local authorities were suspicious of the so-called Jungeste (among whom they also enlisted Eisen, cf. Kallas 1938: 117) while the tsarist authorities generally favoured conversion to Orthodoxy at the time.

9 Kroonlinn in Estonian. This town of about 50,000 people of mixed ethnic origin on Kotlin Island in the vicinity of St Petersburg in the Gulf of Finland was the main fortified Russian naval base in the Baltic Sea. 
${ }^{10}$ Leinbock changed his name to Linnus in 1935.

${ }^{11}$ Nearly all the contributors enlisted have played major roles in the history of the humanities research in Estonia, whereas many of them were only starting their career at the time.

${ }^{12}$ Sööt attended school in Tartu (which became his home town) at the same time that Eisen was a student there, they circulated in the same cultural societies, and Sööt's poetry, particularly in the first decades of the 20th century, was inspired by folk narratives that were mostly collected and published by Eisen (cf. Säärits 1969).

${ }^{13}$ It is quite comparative in size with its 215 pages of shorter contributions of biographical nature and memoirs that comprise 26 entries in total, in contrast to the fewer but longer scholarly writings (cf. Ederberg \& Päss 1938).

${ }^{14} \mathrm{He}$ became the next Lutheran bishop of Estonia.

${ }^{15}$ Eisen often sent these books as presents to his contributors, which further encouraged their enthusiasm and reinitiated the collection process.

${ }^{16}$ I have discussed this topic in greater detail in Kuutma 2005.

${ }^{17}$ Similar concurrences can be detected also in the texts by some other contributors to the memorial album, which undergirds the link between the creation of a biography for public representation with self-representational agendas.

${ }^{18}$ According to the note in his autobiographical manuscript.

${ }^{19}$ EKLA, f. 24, m. 28: 14.

${ }^{20}$ His diary entry from 1928 indicates that he had started with his memoirs about two decades before, while the earliest sheets were misplaced by a publisher (EKLA, f. 24, m. 39: 5). I owe this reference to Rein Saukas.

${ }^{21}$ Original in Estonian: "Aastad Kroonlinnas kulusid rahulikult ilma vahejuhtumisteta; üks aasta täiesti teise sarnane" (EKLA, f. 24, m. 28: 14, 2/10).

${ }^{22}$ See Eisen 2000[1958]: 55 and 129.

${ }^{23}$ Cf. EKLA, f. 24, m. 28: 14, 3/46.

\section{REFERENCES}

Album 1927 = Album M. J. Eiseni 70. sünnipäevaks. Tartu: Eesti Kirjanduse Seltsi ja Eesti Rahva Muuseumi Kirjastus.

Ankersmit, Frank R. 2001[1983]. Six Theses on Narrativist Philosophy of History. In: G. Roberts (ed.) The History and Narrative Reader. London \& New York: Routledge, pp. 237-245.

Ariste, Paul 1938. M. J. Eisen nimede uurijana. In: F. Ederberg \& E. Päss (eds.) M. J. Eiseni elu ja töö. Tartu: Noor-Eesti Kirjastus, pp. 161-162. 
Carroll, Noël 2001. Interpretation, History and Narrative. In: G. Roberts (ed.) The History and Narrative Reader. London \& New York: Routledge, pp. 246-265.

Ederberg, Friedrich Wilhelm 1938a. Matthias Eisen üliõpilasena. In: F. Ederberg \& E. Päss (eds.) M. J. Eiseni elu ja töö. Tartu: Noor-Eesti Kirjastus, pp. 37-57.

Ederberg, Friedrich Wilhelm 1938b. M. J. Eiseni rännuaastad. In: F. Ederberg \& E. Päss (eds.) M. J. Eiseni elu ja töö. Tartu: Noor-Eesti Kirjastus, pp. 58-66.

Ederberg, Friedrich Wilhelm \& Päss, Elmar (eds.) 1938. M. J. Eiseni elu ja töö. Tartu: Noor-Eesti Kirjastus.

Eisen, M. J. 1921. Miten minusta tuli kansanrunouden kerääjä ja Kalevalan harrastaja. Kalevalaseuran vuosikirja, 1, pp. 194-202.

Eisen, M. J. 1925a. Kuidas ma kirjameheks sain. Eesti Kirjandus, No. 9, pp. 343-365.

Eisen, M. J. 1925b. Killud ja dokumendid. Kuidas mind ajakirjandusest eemale tõrjuti. Eesti Kirjandus, No. 9, pp. 396-400.

Eisen, M. J. 1926. Esimene teineteisele lähenemine soome ja eesti üliõpilaste vahel. Eesti ja Soome üliõpilaskondade hõimualbum, Vol. 1, pp. 16-20.

Eisen, M. J. 1931. Isiklikke mälestusi soome-eesti kultuurilistest kokkupuutumistest 50 aasta eest ja neile järgneval ajal. Eesti Kirjandus, No. 3, pp. 169-185.

Eisen, M. J. 2000[1958]. Esivanemate varandus. Ed. by Herbert Tampere. Tallinn: Sinisukk.

Kallas, Oskar 1938. Paar kokkupuudet Eiseniga. In: F. Ederberg \& E. Päss (eds.) M. J. Eiseni elu ja töö. Tartu: Noor-Eesti Kirjastus, pp. 113-117.

Kurrik, Helmi 1938. M. J. Eisen ja Eesti Rahva Muuseum. In: F. Ederberg \& E. Päss (eds.) M. J. Eiseni elu ja töö. Tartu: Noor-Eesti Kirjastus, pp. 179-184.

Kuutma, Kristin 2005. Matthias Johann Eisen: A Collector and Publisher of Narratives. In: K. Kuutma \& T. Jaago (eds.) Studies in Estonian Folkloristics and Ethnology: A Reader and Reflexive History. Tartu: Tartu University Press, pp. 79-99.

Kõpp, Johan 1938. Saateks. In: F. Ederberg \& E. Päss (eds.) M. J. Eiseni elu ja töö. Tartu: Noor-Eesti Kirjastus, pp. 9-10.

Looring, Aleksander 1938a. M. J. Eiseni vanemad, noorpõlv ja kooliaastad. In: F. Ederberg \& E. Päss (eds.) M. J. Eiseni elu ja töö. Tartu: Noor-Eesti Kirjastus, pp. 1136 .

Looring, Aleksander 1938b. M. J. Eisen karsklasena. In: F. Ederberg \& E. Päss (eds.) M. J. Eiseni elu ja töö. Tartu: Noor-Eesti Kirjastus, pp. 185-190.

Loorits, Oskar 1927. Vägilaste prototüüpe. Album M. J. Eiseni 70. sünnipäevaks. Tartu: Eesti Kirjanduse Seltsi ja Eesti Rahva Muuseumi Kirjastus, pp. 37-71.

Mink, Louis O. 1970. History and Fiction as Modes of Comprehension. New Literary History. The Johns Hopkins University Press. Vol. 1, No. 3, pp. 541-558.

Mink, Louis O. 2001. Narrative Form as a Cognitive Instrument. In: G. Roberts (ed.) The History and Narrative Reader. London \& New York: Routledge, pp. 211-220.

Olney, James 1999. Memory and Narrative: The Weave of Life-Writing. Chicago \& London: University of Chicago Press.

Ploompuu, Aleksander 1938. M. J. Eisen Kroonlinna õpetajana (1888-1912). In: F. Ederberg \& E. Päss (eds.) M. J. Eiseni elu ja töö. Tartu: Noor-Eesti Kirjastus, pp. 66-77. 
Päss, Elmar 1938a. M. J. Eiseni õppetööst Tartu ülikoolis. In: F. Ederberg \& E. Päss (eds.) M. J. Eiseni elu ja töö. Tartu: Noor-Eesti Kirjastus, pp. 87-92.

Päss, Elmar 1938b. Eiseni rahvaluulekogudest. In: F. Ederberg \& E. Päss (eds.) M. J. Eiseni elu ja töö. Tartu: Noor-Eesti Kirjastus, pp. 133-139.

Päss, Elmar 1938c. Eiseni enese rahvaluulekirjapanekuist. In: F. Ederberg \& E. Päss (eds.) M. J. Eiseni elu ja töö. Tartu: Noor-Eesti Kirjastus, pp. 140-144.

Päss, Elmar 1938d. Eiseni rahvaluuletrükingute süsteemist. In: F. Ederberg \& E. Päss (eds.) M. J. Eiseni elu ja töö. Tartu: Noor-Eesti Kirjastus, pp. 145-160.

Päss, Elmar 1938e. Lisandeid M. J. Eiseni bibliograafiale. In: F. Ederberg \& E. Päss (eds.) M. J. Eiseni elu ja töö. Tartu: Noor-Eesti Kirjastus, pp. 191-213.

Rahamägi, Hugo Bernhard 1938. Isa Eisen ülikooli koguduses ja kirikus. In: F. Ederberg \& E. Päss (eds.) M. J. Eiseni elu ja töö. Tartu: Noor-Eesti Kirjastus, pp. 93-99.

Roos, Jaan 1938. M. J. Eiseni pedagoogiline töö. In: F. Ederberg \& E. Päss (eds.) M. J. Eiseni elu ja töö. Tartu: Noor-Eesti Kirjastus, pp. 78-86.

Säärits, Endel 1969. Karl Eduard Sööt ja Anna Haava. In: E. Sõgel \& H. Puhvel (eds.) Eesti kirjanduse ajalugu: XIX sajandi lõpust 1917. aastani. Tallinn: Kirjastus Eesti Raamat, Vol. 3, pp. 67-81.

Smith, Sidonie \& Watson, Julia 2000. Reading Autobiography: A Guide for Interpreting Life Narratives. Minneapolis \& London: University of Minnesota Press.

Sööt, Karl Eduard 1927. M. J. Eiseni elust ja tegevusest. Album M. J. Eiseni 70. sünnipäevaks. Tartu: Eesti Kirjanduse Seltsi ja Eesti Rahva Muuseumi Kirjastus, pp. 1-15.

Sööt, Karl Eduard 1938a. Märkmeid luuletaja loominguteilt. In: F. Ederberg \& E. Päss (eds.) M. J. Eiseni elu ja töö. Tartu: Noor-Eesti Kirjastus, pp. 125-129.

Sööt, Karl Eduard 1938b. M. J. Eiseni ajakirjanduslikust tööst. In: F. Ederberg \& E. Päss (eds.) M. J. Eiseni elu ja töö. Tartu: Noor-Eesti Kirjastus, pp. 167-175.

Tampere, Herbert 2000 [1958]. M. J. Eisen ja "Esivanemate varandus". In: M. J. Eisen. Esivanemate varandus. Tallinn: Sinisukk, pp. 250-257.

Tedre, Ülo 1995. Matthias J. Eisen rahvausundi uurijana. In: M. J. Eisen. Esivanemate ohverdamised. Tallinn: Mats, pp. 170-177.

White, Hayden 1978. The Historical Text as Literary Artefact. In: H. White (ed.) Tropics of Discourse: Essays in Cultural Criticism. Baltimore \& London: John Hopkins University Press, pp. 82-93.

White, Hayden 1992. Historical Emplotment and the Problem of Truth. In: S. Friedlander (ed.) Probing the Limits of Representation. Nazism and the "Final Solution”. Cambridge, MA: Harvard University Press, pp. 37-53. 